chemical reactions have been studied for the first time. The active isotopes of carbon, phosphorus, sodium, calcium and other elements of special importance in biology make it possible to investigate the metabolism of these atoms. The use of radioelements as indicators is steadily increasing and it is to be expected that in future many chemical, physical and biological laboratories will avail themselves of the great possibilities offered by this method in the study of an infinite variety of problems.

\section{Bird Preservation}

THE British Section of the International Committee for Bird Preservation, of which Dr. Percy Lowe is chairman and Mr. D. Seth-Smith treasurer, is appealing for support. It is governed by a committee of sixteen drawn from the Royal Society, the Royal Society of Edinburgh, the Zoological Society of London, the British Ornithologists' Union, the Royal Society for the Protection of Birds, the National Trust, the Society for the Promotion of Nature Reserves and the Society for the Preservation of the Fauna of the Empire. The British Section is not only representative of bird protection interests in Great Britain but, in addition, is in direct communication with similar sections of twenty-six nations. Its work is essentially international in character and deals with problems which can only be solved by scientific and even 'political' work on a very wide front. These include the drafting of a new international convention for the protection of European birds ; the destruction of birds by waste oil at sea ; the protection of the quail, which is caught in thousands during the breeding season for export to European countries; the conditions under which live birds are transported by sea; and an inquiry into the status of the Anatidæ. This latter, which is regarded as vitally important by scientific workers and sportsmen throughout Europe, includes investigations ranging from the conditions obtaining in northern breeding grounds to the diminution of Zostera marina. Of paramount importance is a scheme for ringing duck in order to trace their lines of migration. To carry out this work adequately it is essential that the income of the British Section should be greatly increased. All persons interested are therefore invited to become either patrons at three guineas or associates at $10 s$. 6d. a year. Subscriptions should be sent to the Secretary, Miss Phyllis Barclay-Smith, British Section, I.C.B.P., c/o Zoological Society of London, Regent's Park, N.W.8.

\section{Town Planning and Decentralization}

THE relationship of man to his work and his environment was explored from various aspects at a conference held by the Garden Cities and Town Planning Association, at the Housing Centre, 13 Suffolk Street, S.W.1, on February 27. Dr. Norman MacFayden, former medical officer of health for Letchworth, showed statistically that the satellite town has proved its great value from the health point of view; his comparative figures for tuberculosis and pneumonia were particularly convincing.
He stressed the close relationship between man and Nature which is taken into account in the planning of garden cities, but which the modern congested cities, for example, London, Manchester, Glasgow, cannot provide. The case for the satellite town was further strengthened by papers presented by G. L. Pepler, Colin Clarke and Dr. D. H. Smith. Dr. Smith gave a full account of the uncontrolled location of industries in the Lea Valley on the outskirts of London, and pointed out that in the great majority of cases there was no reason why the factories should not have been located at a greater distance, within satellite towns. He listed a number of problems : noise, traffic congestion, traffic control, vulnerability in war time, journeys to work, as well as health and æsthetic aspects which should be further investigated and could be solved by decentralization. Mr. Colin Clarke estimated the change in the proportion of workers employed in manufacturing industries for 'export' and as compared with local industries and services, and concluded that the increase in the latter, following upon an increased standard of living, will also favour decentralization during the coming decades.

\section{Electricity Supply in Great Britain}

ON March 3, in reply to a question by Sir M. Macdonald, Mr. Hore-Belisha, the Minister of Trans. port, said that his Majesty's Government has decided to adopt in principle the recommendations of the MeGowan Committee for a reorganization of electricity supply of the country. A few minor modifications would be added, which he understood would be generally acceptable. In the report it is stated that any attempt to carry through a scheme of reorganization on a voluntary basis would fail, and legislation must confer definite and adequate compulsory powers. It is also stated that schemes of reorganization should make provision for the possibility of ultimate public ownership of all undertakings, including those not at present subject to purchase by the local authorities. Complete standardization of systems and voltages and of methods of charge, as well as amalgamation of a large number of small undertakings into a smaller number of large ones will be necessary. As a result of such reorganization, considerable further development of rural areas should be possible. The scheme recommended by the McGowan Committee should result in a general, though necessarily gradual, reduction in costs. It rejects nationalization as a solution of the distribution problem, at least in the present stage of the evolution of the industry. It prefers to proceed by the gradual method of overhaul and consolidation and a more efficient grouping of existing undertakings. In a report published last December by PEP (Political and Economic Planning, 16 Queen Anne's Gate, S.W.1), the problem is summed up by saying that the public expects that the supply industry will hasten towards a future where the residential consumer, the farmer and the industrialist will have full freedom to use electricity to the greatest advantage. This will obviously take several years. 